\title{
EVALUASI PREMI POLIS LAST SURVIVOR PASANGAN SUAMI ISTRI MENGGUNAKAN METODE COPULA FRANK
}

\author{
Irma Fauziah1 \\ ${ }^{1}$ Program Matematika Fakultas Sains dan Teknologi Universitas Islam Negeri Syarif Hidayatullah Jakarta \\ e-mail : irma_s2mathUGM@yahoo.com atau irmaristianto08@gmail.com
}

\begin{abstract}
ABSTRAK
Tulisan ini mengkaji tentang sebuah produk asuransi, ketahanan hidup, yang didasarkan pada dua kelompok umur: pasangan menikah berusia kurang dari 55 tahun dan menikah berusia lebih dari 55 tahun. Penilaian premi untuk pasangan menikah yang kurang dari 55 tahun diperoleh dengan metode Frasier dengan memperhitungkan probabilitas kematian setelah kematian terjadi dari salah satu tertanggung dengan asumsi kematian pasangan menikah adalah independen. Sedangkan untuk pasangan yang sudah menikah lebih dari 55 tahun, premi penilaian diperoleh dengan metode Frasier untuk menghitung probabilitas kematian dengan menganggap kematian pasangan menikah adalah dependen, asumsi ini dimodelkan oleh Frank kopula, dimana kopula ini adalah salah satu dari keluarga kopula Archimedes.
\end{abstract}

Kata kunci: Metode Frasier, Frank Copula, Hidup Bersama dan Status Terakhir

\section{ABSTRACT}

This paper introduces an insurance product, Survivorship, based on two age groups : married couples less than 55 years old and married couples over 55 years old. Premiums Valuation for married couples who less than 55 years are obtained using Frasier method with take into account the lapse rate after death occurs from one of the insured with mortality assumption of married couples are independent. While for married couples over 55 years, premiums valuation are obtained using Frasier method for calculating the probability of death by assuming mortality of married couples are dependent, this assumption is modeled by Frank copula. This copula is one of family Archimedean copula.

Keywords : Frasier Methods, Frank Copula, Joint Life and Last Survivor Status

\section{PENDAHULUAN}

Di Indonesia, polis asuransi single life lebih mendominasi produk-produk asuransi di setiap perusahaan asuransi, sedangkan polis asuransi last survivor belum begitu banyak mendapat perhatian. Di Kanada, Industri asuransi menetapkan harga polis asuransi last survivor menggunakan metode Frasier untuk menaksir probabilitas kematian tertanggung dengan mengasumsikan mortalitas pasangan suami istri adalah saling bebas. Metode ini menaksir probabilitas kematian dari tertanggung terakhir pada polis last survivor pada tahun tertentu yang telah dihitung pada awal tahun berlakunya polis last survivor.

Polis last survivor adalah polis asuransi jiwa yang menanggung minimal dua orang dimana benefitnya dibayarkan jika semua tertanggung meninggal dunia. Jika tertanggungnya merupakan pasangan suami istri maka ada beberapa hal yang harus dianalisis terkait valuasi premi last survivor yaitu :
1. Resiko yang dialami pasangan suami istri pasangan suami istri kurang lebih mempunyai resiko yang sama diantaranya :

a. Penyakit menular (Margus P, 2002) seperti Tubelkolosis (Gusti Arlina, 2003) dan penyakit kelamin seperti HIV, AIDS, Hepatitis B (Dr.M. Atoillah I, 2007)

b. Kecelakaan yang dialami bersama (Martikeinan P, Valkonen T, 1996)

c. Stress Cardiomyopathy (Parkes, 1969 ; Martikeinan P, 1996; dan Heekyung Youn, Arkady Shemyakin, 1999). Menurut Parkes, stress cardiomyopathy terjadi pada pasangan suami istri yang berusia 55 tahun ke atas.

2. Faktor Lapse

Lapse adalah kejadian dimana pemegang polis tidak melanjutkan kontraknya disebabkan tidak sanggup membayar premi. 
Berdasarkan pertimbangan dua faktor tersebut maka dapat disimpulkan produk asuransi jiwa last survivor dengan asumsi mortalitas pasangan suami istri saling dependen yang keduanya hanya dikhususkan untuk pasangan suami istri yang keduanya berusia 55 tahun keatas. Sedangkan faktor lapse setelah terjadi kematian dari salah satu pasangan suami istri dan asmsi bahwa mortalitas pasangan suamiistri adalah independen diperhitungkan untuk pemegang polis last survivor dengan usia pasangan suami istri kurang dari 55 tahun.

Tulisan ini hanya terbatas pada perhitungan premi tunggal bersih asuransi jiwa last survivor berjangka 10 tahun yang dihitung menggunakan tabel multilife yang memuat angka klaim Frasier yang diturunkan dari tabel mortalitas single life US female and Male tahun 2004.

\section{LANDASAN TEORI}

\section{A. Bunga Majemuk}

Semua polis asuransi jiwa baik single life maupun multilife mengharuskan premi dibayar di muka sebelum asuransi efektif sedangkan benefit baru akan dibayarkan pada masa yang akan datang sehingga premi itu dikenakan bunga. Oleh karena itu, perhitungan bunga pada asuransi menggunakan teknik perhitungan bunga majemuk dan diskonto. Akumulasi bunga majemuk dari dana sebesar Rp 1,. adalah

$$
a(t)=(1+i)^{t}, \quad \text { untuk } t \geq 0
$$

dengan $i$ menyatakan suku bunga dalam satu periode. Faktor diskonto dinotasikan dengan $v^{t}$ yang diberikan oleh,

$$
a^{-1}(t)=v^{t}=\frac{1}{(1+i)^{t}} \text { untuk } t \geq 0
$$

\section{B. Status Single Life}

\section{a) Fungsi Survival}

Misalkan X adalah variabel random kontinu yang menyatakan jatah usia yang akan dijalani oleh seorang bayi yang baru lahir, maka fungsi distribusi dari $\mathrm{X}$ adalah

$$
F_{X}(x)=\operatorname{Pr}(X \leq x), \quad x \geq 0
$$

dan fungsi survival yang menyatakan probabilitas seorang bayi yang baru lahir akan mencapai usia $\mathrm{x}$ tahun adalah

$$
s(x)=1-F_{X}(x)=\operatorname{Pr}(X>x), x \geq 0
$$

\section{b) Sisa Usia Bagi $(x)$}

Notasi $T(x)$ menyatakan sisa usia dari $(x)$ dinyatakan dengan $T(x)=X-x$. Notasi aktuaria yang berhubungan dengan probabilitas tentang $T(x)$ dinyatakan sebagai,

1. Probabilitas $(x)$ akan meninggal $t$ tahun kemudian dinyatakan sebagai berikut:

$$
\begin{aligned}
{ }_{x} q_{x} & =\operatorname{Pr}(T(x) \leq t) \\
& =1-\frac{s(x+t)}{s(x)}, \quad t \geq 0
\end{aligned}
$$

2. Probabilitas $(x)$ akan hidup mencapai usia $x+t$ tahun dinyatakan sebagai berikut:

$$
\begin{aligned}
{ }_{t} p_{x} & =1-{ }_{t} q_{x}=\operatorname{Pr}(T(X)>t) \\
& =\frac{s(x+t)}{s(x)}, \quad t \geq 0
\end{aligned}
$$

\section{c) Sisa Usia Bulat Bagi ( $x$ )}

Variabel random yang berhubungan dengan sisa usia bulat untuk $(x)$ sampai terjadi kematian dinotasikan dengan $K(x)$. Fungsi distribusi dari $K(x)$ didefinisikan sebagai :

$$
F_{K(x)}(y)=\sum_{h=0}^{k}{ }_{h} q_{x}={ }_{k+1} q_{x}, \quad y \geq 0
$$

dan $\mathrm{k}$ bilangan bilat terbesar dari y.

\section{d) Hubungan Tabel Mortalitas dan Fungsi Survival}

Misalkan $£(x)$ merupakan variabel random yang menyatakan jumlah orang yang masih hidup sampai usia $\mathrm{x}$ tahun yang dinyatakan dengan

$$
£(x)=\sum_{j=1}^{l_{0}} I_{j}(x)
$$

1. $€(x) \sim \operatorname{Binomial}\left(l_{0}, s(x)\right)$

2. $I_{j} \sim$ Bernoulli dengan

$$
I_{j}= \begin{cases}1, & j \text { masih hidup sampai usia } x \\ 0, & j \text { meninggal sebelum usia } x\end{cases}
$$

Karena $E\left[I_{j}\right]=s(x)$ maka $l_{x}=E[E(x)]=$ $l_{0} s(x)$. Probabilitas seseorang yang berusia $x$ akan hidup paling sedikit $k$ tahun yaitu ${ }_{k} p_{x}=\frac{l_{x+k}}{l_{x}}$ maka probabilitas seseorang berusia $x$ akan meninggal sebelum mancapai usia $x+k$ tahun adalah

$$
{ }_{k} q_{x}=1-{ }_{k} p_{x}=\frac{l_{x+k}-l_{x}}{l_{x}}=\frac{d_{x}}{l_{x}}
$$

Tabel mortalitas yang digunakan dalam tulisan ini adalah life table US male\&female 2004. 


\section{e) Sistem Pembayaran Benefit Asuransi Single Life Berjangka Diskrit}

Misalkan $b_{k+1}$ menyatakan fungsi benefit dan $v^{k+1}$ menyatakan fungsi diskonto maka asuransi berjangka $n$ tahun yang menyediakan benefit pada akhir tahun kematian tertanggung adalah

$b_{k+1}=\left\{\begin{array}{rr}1, & k=0,1, \ldots, n-1 \\ 0, & \text { yang lain }\end{array}\right.$

Untuk mempermudah perhitungan, asumsikan benefitnya sebesar Rp 1,. Present Value pembayaran benefit adalah sebesar $Z_{k+1}=b_{k+1} \cdot v^{k+1}$ Variabel random dari $Z_{k+1}$ dinotasikan dengan $\mathrm{Z}$.

$Z=\left\{\begin{array}{c}v^{k+1}, K=0,1, \ldots, n-1 \\ 0, \quad \text { yang lain }\end{array}\right.$

Actuarial Presesnt Value (APV) dari asuransi berjangka $\mathrm{n}$ tahun adalah

$$
\begin{aligned}
E[Z]=E\left[v^{k+1}\right] & =\sum_{k=0}^{n-1} v^{k+1} \operatorname{Pr}[K(x)=k] \\
& =\sum_{k=0}^{n-1}{ }_{k \mid} q_{x}=A_{x: n}^{1}
\end{aligned}
$$

\section{f) Anuitas Jiwa Single Life Berjangka $n$ Tahun Diskrit}

Present Value variabel random dari anuitas jiwa awal berjangka $n$ tahun sebesar 1 pertahun adalah

$$
Y=\left\{\begin{array}{lr}
\ddot{a}_{\overline{K+1 \mid}} & 0 \leq K \leq n \\
\ddot{a}_{\overline{n \mid}} & K \geq n
\end{array}\right.
$$

dan actuarial present value (APV) nya adalah

$$
E[Y]=\sum_{k=0}^{n-1} \ddot{a}_{\overline{k+1}{ }_{k}} p_{x} q_{x+k}+\ddot{a}_{n}{ }_{n} p_{x}=\sum_{k=0}^{n-1} v_{k}^{k}{ }_{k} p_{x}=\ddot{a_{x: n}}
$$

\section{g) Status Last Survivor}

Kelangsungan status dari $m$ individu yang berusia $x_{1}, x_{2}, \ldots, x_{m}$ masih berlangsung jika paling sedikit satu dari $\left(x_{1}\right),\left(x_{2}\right), \ldots,\left(x_{m}\right)$ hidup dan status ini akan berkahir jika semua individu meninggal dunia dinamakan status Last Survivor. Status ini dinotasikan dengan $\left(\overline{x_{1} x_{2} \ldots x_{m}}\right)$. Distribusi sisa usia yang lengkap yang akan dijalani oleh status last survivor yaitu:

$$
K\left(\overline{x_{1} x_{2} \ldots x_{m}}\right)=\max \left[K\left(x_{1}\right), K\left(x_{2}\right), \ldots, K\left(x_{m}\right)\right]
$$

dengan $K\left(x_{i}\right)$ adalah sisa usia lengkap yang dijalani oleh individu ke-i. Misalkan status last survivor pasangan suami istri dengan $x$ menyatakan usia suami dan $y$ menyatakan usia istri maka fungsi distribusi dari $K(\overline{x y})$ dengan asumsi sisa usia pasangan suami istri adalah saling bebas dinyatakan sebagai,

$$
\begin{aligned}
\operatorname{Pr}(K(\overline{x y})=k) & =f_{K(\overline{x y})}(k) \\
& ={ }_{k} q_{y k} p_{x k} q_{x+k} \\
& ={ }_{k} q_{y k} p_{y k} q_{y+k} \\
& ={ }_{k} p_{x y} q_{x+k} q_{y+k}
\end{aligned}
$$

Probabilitas salah seorang pasangan suami istri akan hidup $k$ tahun dinotasikan dengan

$$
{ }_{k} p_{\overline{x y}}={ }_{k} p_{x y}+{ }_{k} p_{x k} q_{x}+{ }_{k} p_{y{ }_{k}} q_{x}
$$

\section{Sistem Pembayaran Benefit Asuransi Last Survivors Berjangka Diskrit}

Jika $\mathrm{K}$ menyatakan sisa usia lengkap dari status $(\overline{x y})$ maka

1. Waktu pembayaran adalah $\mathrm{K}+1$

2. Present Value pada pembayaran benefit ini pada saat polis dikeluarkan sebesar $\mathrm{Z}=v^{K+1}$.

3. Actuarial Present Value (APV) yaitu :

$$
E[Z]=E\left[v^{k+1}\right]=\sum_{k=0}^{n-1} v^{k+1} \operatorname{Pr}(K(\overline{x y})=k)=A_{x y: n}^{1}
$$

\section{Anuitas Jiwa Last Survivors Berjangka $n$ Tahun Diskrit}

Actuarial present value (APV) dari anuitas Last Survivor berjangka $\mathrm{n}$ tahun adalah :

$$
E[Y]=\sum_{k=0}^{n-1} \ddot{a}_{\overline{k+1}} \operatorname{Pr}(K(\overline{x y})=k)+\ddot{a}_{n}{ }_{n} p_{\overline{x y}}=\ddot{a}_{\overline{x y}: n}
$$

\section{E. Copula Frank}

Copula Frank merupakan salah satu keluarga copula Archimedean dan pertama kali dikenalkan oleh Frank pada tahun 1979 yang mempunyai bentuk :

$$
\begin{aligned}
& C(u, v)=\frac{1}{\alpha} \times \ln \left[1-\frac{\left(1-e^{\alpha u}\right) \times\left(1-e^{\alpha \nu}\right)}{1-e^{\alpha}}\right], \\
& -\infty<\alpha<\infty
\end{aligned}
$$

A adalah parameter yang mengukur penyimpangan dari asumsi saling bebas. Copula ini dibangun dari fungsi pembangkit (generator) yang dinotasikan dengan $\varphi(u)$ yaitu :

$$
\varphi(u)=\ln \frac{e^{\alpha u}-1}{e^{\alpha}-1}
$$


dengan fungsi invers yaitu :

$\varphi^{-1}(u)=\frac{\ln \left(1+e^{u}\left(e^{\alpha}-1\right)\right)}{\alpha}$

Copula ini mempunyai kelebihan jika dibandingkan dengan keluarga copula Archimedean yang lain yaitu :

1. Dependensi lengkap, copula Frank mengijinkan dependensi negative antar marginal, $-\infty<\alpha<\infty$

2. Copula ini digunakan untuk memodelkan data yang menunjukkan dependensi yang lemah

3. Mempunyai batas-batas Frechet-Hoeffding yang termuat dalam interval parameter dependensi.

\section{PEMBAHASAN}

\section{A. Status Polis Last Survivor}

Dalam polis Last Survivor yang menanggung pasangan suami yang berusia $x$ tahun dan istri yang berusia $y$ tahun maka terdapat empat status yang bergantung pada status hidup keduanya, misalkan A, B, C dan D adalah empat status tersebut dengan status $A$ menyatakan status pasutri keduanya masih hidup, status B menyatakan status bahwa istri masih hidup dan suami sudah meninggal, status $\mathrm{C}$ menyatakan status istri sudah meninggal dan suami masih hidup dan status D menyatakan status bahwa keduanya sudah meninggal. Jadi asumsi mortalitas pada keempat status merupakan bobot rata-rata angka mortalitas yang ditunjukkan pada Tabel 1.

Tabel 1. Populasi dan Status

\begin{tabular}{|c|c|c|c|c|}
\hline Status & $\mathrm{TP}(\mathrm{x})$ & $\mathrm{TK}(\mathrm{y})$ & PSPAT $(\mathrm{k}+1)$ & $P I F$ \\
\hline $\mathrm{A}$ & $\mathrm{h}$ & $\mathrm{h}$ & ${ }_{k}^{A} p_{x y}={ }_{k} p_{x} p_{y}$ & ya \\
$\mathrm{B}$ & $\mathrm{m}$ & $\mathrm{h}$ & ${ }_{k}^{B} p_{x y}={ }_{k} q_{x k} p_{y}$ & ya \\
$\mathrm{C}$ & $\mathrm{h}$ & $\mathrm{m}$ & ${ }_{k}^{C} p_{x y}={ }_{k} p_{x k} q_{y}$ & ya \\
$\mathrm{D}$ & $\mathrm{m}$ & $\mathrm{m}$ & ${ }_{k}^{D} p_{x y}={ }_{k} q_{x k} q_{y}$ & tidak \\
\hline
\end{tabular}

Keterangan.

$\mathrm{H} \quad$ : hidup

M : meninggal

TP : tertanggung pertama

TK : tertanggung kedua

PSPAT : probabilitas status pada awal tahun

PIF : policy in force

\section{B. Angka Klaim Last Survivor Frasier}

Bill Frasier pada tahun 1978 mengenalkan metode pendekatan untuk menghitung probabilitas kematian pada tahun tertentu dari tertanggung terakhir, yang dihitung pada awal berlakunya polis, angka klaim tersebut dinyatakan dengan,

$$
\begin{gathered}
q_{k}^{J L S}=\frac{\left({ }_{k} p_{x k} p_{y}\right) \times\left(q_{x+k} q_{y+k}\right)+\left({ }_{k} p_{x k} q_{y}\right) \times q_{x+k}+\left({ }_{k} q_{x k} p_{y}\right) \times q_{y+k}}{\left({ }_{k} p_{x k} p_{y}\right)+\left({ }_{k} p_{x k} q_{y}\right)+\left({ }_{k} q_{x k} p_{y}\right)} \\
=\frac{{ }_{k+1} q_{\overline{x y}}-{ }_{k} q_{\overline{x y}}}{1-{ }_{k} q_{\overline{x y}}}
\end{gathered}
$$

Dengan ${ }_{k} q_{\overline{x y}}$ menyatakan probabilitas bahwa kedua tertanggung meninggal dalam $\mathrm{k}$ tahun pertama.

Persamaan (22) dapat dinyatakan sebagai probabilitas bersyarat, yaitu :

$q_{k}^{J L S}=\frac{{ }_{k}^{A} p_{x y} \times q_{\overline{x+k: y+k}}+{ }_{k}^{B} p_{x y} \times q_{y+k \mid x m e n i n g g a l}+{ }_{k}^{C} p_{x y} \times q_{x+k \mid y m e n i n g g a l}}{{ }_{k}^{A} p_{x y}+{ }_{k}^{B} p_{x y}+{ }_{k}^{C} p_{x y}}$

Populasi status A akan berkurang karena terjadi kematian salah satu tertanggung maka polis bermigrasi ke status B dan C dan jika keduanya meninggal maka polis bermigrasi ke status D.

Secara rekursif dinyatakan sebagai :

\begin{tabular}{lll}
\hline & KTBN & MTBN \\
\hline${ }_{k+1}^{A} p_{x y}={ }_{k}^{A} p_{x y}$ & $-{ }_{k}^{A} p_{x y} \times q_{\overline{x+k, y+k}}$ & $-{ }_{k}^{A} p_{x y} \times\left(q_{y+k \mid x_{h}}-q_{\overline{x+k, y+k}}\right)$ \\
${ }_{k+1}^{B} p_{x y}={ }_{k}^{B} p_{x y}$ & $-{ }_{k}^{B} p_{x y} \times q_{x+k \mid y_{m}}$ & $-{ }_{k}^{A} p_{x y} \times\left(q_{y+k \mid y_{h}}-q_{\overline{x+k, y+k}}\right)$ \\
${ }_{k+1}^{C} p_{x y}={ }_{k} p_{x y}$ & $-{ }_{k}^{C} p_{x y} \times q_{y+k \mid x_{m}}$ & $-{ }_{k}^{A} p_{x y} \times\left(q_{y+k \mid x_{h}}-q_{\overline{x+k, y+k}}\right)$ \\
${ }_{k+1}^{D} p_{x y}={ }_{k} p_{x y}$ & $-{ }_{k}^{A} p_{x y} \times q_{\overline{x+k, y+k}}$ & $-{ }_{k}^{A} p_{x y} \times\left(q_{y+k \mid y_{m}}-q_{\overline{x+k, y+k}}\right)$ \\
& & $+-{ }_{k}^{B} p_{x y} \times q_{x+k \mid y_{m}}$ \\
& & $+-{ }_{k}^{C} p_{x y} \times q_{y+k \mid x_{m}}$ \\
& &
\end{tabular}

Keterangan.

KTBN : klaim total bersih nol

MTBN : migrasi total bersih nol

\section{Pengaruh Tingkat Lapse pada Setiap Status}

Jika data tidak tersedia maka seorang aktuaris boleh mengasumsikan tingkat lapse yang lebih rendah diantara tertanggung yang masih hidup (Margus, 2002).

Untuk menetapkan jumlah populasi pada tahun berikutnya berdasarkan asumsi tingkat lapse yang diberikan, secara terpisah pada setiap status yang berlaku maka,

status A, ${ }_{k+1}^{A} P_{x y}={ }_{k}^{A} P_{x y}^{e . o . y} \times\left(1-{ }_{k+1}^{A} r_{x y}\right)$

status $\mathrm{B},{ }_{k+1}^{B} P_{x y}={ }_{k}^{B} P_{x y}^{e . o . y} \times\left(1-{ }_{k+1}^{B} r_{x y}\right)$

status $\mathrm{C},{ }_{k+1}^{C} P_{x y}={ }_{k}^{C} P_{x y}^{e . o . y} \times\left(1-{ }_{k+1}^{C} r_{x y}\right)$

dimana ${ }_{k+1}^{A} r_{x y}$ menyatakan tingkat lapse pada akhir tahun ke $k+1$ pada status $\mathrm{A},{ }_{k+1}{ }^{B} r_{x y}$ menyatakan tingkat lapse pada akhir tahun ke 
$k+1$ pada status $\mathrm{B},{ }_{k+1}^{C} r_{x y}$ menyatakan tingkat lapse pada akhir tahun ke $k+1$ pada status $\mathrm{C}$, dan notasi ${ }_{k}^{A} P_{x y}^{\text {e.o.y }}$ menyatakan probabilitas hidup atau populasi akhir tahun ke- $k$ pada status A yang besarnya dinyatakan dengan

$$
\begin{aligned}
& { }_{k}^{A} p_{x y}^{e . o . y}={ }_{k}^{A} p_{x y}-{ }_{k}^{A} p_{x y} \times q_{\overline{x+k: y+k}} \\
& -{ }_{k}^{A} p_{x y} \times\left(q_{y+k \mid x h i d u p}-q_{\overline{x+k: y+k}}\right) \\
& -{ }_{k}^{A} p_{x y} \times\left(q_{x+k \mid y h i d u p}-q_{\overline{x+k: y+k}}\right)
\end{aligned}
$$

Persamaan ini diperoleh dari persamaan (24), dimana persamaan (24) merupakan populasi awal tahun. Sedangkan status D adalah status dimana keduanya meninggal maka populasi status D tidak berubah.

\section{Model Copula Frank untuk Anuitas dan Asuransi Berjangka Last Survivor}

Notasi $(\overline{x y})$ menyatakan status dari dua tertanggung yang berusia $x$ dan $y$ tahun masih berlangsung jika salah satu dari $(x)$ atau $(y)$ masih hidup dan status tersebut berakhir jika keduanya meninggal dunia disebut status Last Survivor.

Probabilitas salah satu tertanggung dari suami ataupun istri akan hidup mencapai usia $x+k$ dan $y+k$ tahun dinotasikan dengan ${ }_{k} p_{\overline{x y}}$, berdasarkan copula Frank dinyatakan sebagai ${ }_{k} p_{\overline{x y}}=1-\left(\frac{1}{\alpha} \times \log _{e}\left(1-\frac{\left(1-e^{\alpha_{k} q_{x}}\right)\left(1-e^{\alpha_{k} q_{y}}\right)}{1-e^{\alpha}}\right)\right)$

Anuitas awal berjangka $n$ tahun untuk status Last Survivor dinotasikan dengan $\ddot{a}_{\overline{x y}: \bar{n}}$ yang besarnya adalah,

$$
\ddot{a}_{x y: n}=\sum_{k=0}^{n-1} v^{k}\left[1-\left(\frac{1}{\alpha} \times \log _{e}\left(1-\frac{\left(1-e^{\alpha_{k} q_{x}}\right)\left(1-e^{\alpha_{k} q_{y}}\right)}{1-e^{\alpha}}\right)\right)\right]
$$

Nilai tunai asuransi atau premi tunggal bersih asuransi Last Survivor sebesar Rp 1,. selama $\mathrm{n}$ tahun adalah

$$
\begin{aligned}
A_{x y: n}^{1} & =\sum_{k=0}^{n-1} v_{k}^{k+1} p_{\overline{x y}} q_{k}^{J L S} \\
& =\sum_{k=0}^{n-1} v^{k+1}\left[\frac{1}{\alpha} \log _{e}\left(\frac{\left(1-e^{\alpha}\right)-\left(1-e^{\alpha_{\cdot k+1} q_{x}}\right)\left(1-e^{\alpha_{\cdot k+1} q_{y}}\right)}{\left(1-e^{\alpha}\right)-\left(1-e^{\alpha_{\cdot k} q_{x}}\right)\left(1-e^{\alpha_{\cdot k} q_{y}}\right)}\right)\right]
\end{aligned}
$$

\section{E. Model Copula Frank untuk Premi Last Survivor}

Misalkan premi tunggal bersih untuk asuransi Last Survivor berjangka $\mathrm{n}$ tahun dengan benefit sebesar Rp 1,. bagi suami yang berusia $x$ tahun dan istri yang berusia $y$ tahun dinotasikan dengan $P_{x y: n}^{1}$.

Fungsi kerugian:

$$
\begin{aligned}
& L=v^{k+1}-P_{\overline{x y}: n}^{1}\left(\ddot{a_{\overline{k+1}}}+\ddot{a}_{n}{ }_{n} p_{\overline{x y}}\right) \quad k=0,1,2, \ldots, n-1 \\
& E[L]=0 \Leftrightarrow E\left[v^{k+1}\right]-P_{x y: n}^{1}\left(E\left[\ddot{a_{\overline{k+1}}}+\ddot{a}_{n}{ }_{n} p_{\overline{x y}}\right]\right)=0 \\
& \Leftrightarrow P_{x y: n}^{1}=\frac{\sum_{k=0}^{n-1} v^{k+1}\left[\frac{1}{\alpha} \log _{e}\left(\frac{\left(1-e^{\alpha}\right)-\left(1-e^{\alpha_{\cdot k+1} q_{x}}\right)\left(1-e^{\alpha_{k+1} q_{y}}\right)}{\left(1-e^{\alpha}\right)-\left(1-e^{\alpha_{\cdot k} q_{x}}\right)\left(1-e^{\alpha_{k} q_{y}}\right)}\right)\right]}{\sum_{k=0}^{n-1} v^{k}\left[1-\left(\frac{1}{\alpha} \times \log _{e}\left(1-\frac{\left(1-e^{\alpha_{\cdot k} q_{x}}\right)\left(1-e^{\alpha_{k} q_{y}}\right)}{\left(1-e^{\alpha}\right)}\right)\right]\right]}
\end{aligned}
$$

\section{Contoh}

1. Karena ketidak tersediaan data di lapangan, maka sebagai contoh andaikan pasangan suami istri yang mempunyai usia lebih dari 55 tahun mengalihkan resiko ketidakpastian hidup dengan mengikuti asuransi berjangka last survivor berjangka dengan masa asuransi 10 tahun, pasangan suami istri tersebut berturut-turut berusia 60 tahun dan 55 tahun, dengan uang pertanggungan sebesar Rp. 100 000 000,. dan suku bunga 6\% pertahun, parameter dependensi mortalitas pasutri dihitung menggunakan copula Frank dengan mengambil nilai parameter $\alpha=-3,367,-3,-2,5$, $-2,-1,5,-1$ dan 1(Valdez, Frees, dan Carriere, 1999) maka premi tahunan netto nya adalah :

Tabel 2. Premi Netto Tahunan Berjangka 10 tahun Untuk suami yang berusia 60 tahun dan Istri yang berusia 55 tahun

\begin{tabular}{ccc}
\hline UPSI & $\mathrm{P}(\alpha)$ & PTN $(\mathrm{Rp})$ \\
\hline $\mathrm{x}=60$ & -3.367 & 292506.01 \\
$\mathrm{y}=55$ & -3 & 273782.33 \\
& -2.5 & 247579.07 \\
& -2 & 220892.55 \\
& -1.5 & 194163.79 \\
& -1 & 167914.84 \\
& 1 & 78471.49 \\
\hline
\end{tabular}

Keterangan.

UPSI : usia pasangan suami-istri

P : parameter

PTN : premi tahunan netto

dengan perhitungan sebagai berikut:

\begin{tabular}{ccccc}
\hline $\begin{array}{c}\mathrm{x}=60 \\
\mathrm{y}=55\end{array}$ & $\begin{array}{c}(1) \\
\text { Mortalitas } \\
\mathrm{k}\end{array}$ & $\begin{array}{c}(2) \\
\text { Single } \\
\mathrm{q}_{\mathrm{x}+\mathrm{k}}\end{array}$ & $\begin{array}{c}(3) \\
\text { Life } \\
\mathrm{kq}_{\mathrm{x}}\end{array}$ & $(4)$ \\
\hline 0 & 0.01176 & 0.00472 & 0.00000 & 0.00000 \\
1 & 0.01293 & 0.00514 & 0.01176 & 0.00472 \\
2 & 0.01416 & 0.00559 & 0.02454 & 0.00984 \\
3 & 0.01536 & 0.00611 & 0.03836 & 0.01538 \\
4 & 0.01656 & 0.00670 & 0.05313 & 0.02139 \\
5 & 0.01785 & 0.00739 & 0.06881 & 0.02795 \\
6 & 0.01933 & 0.00817 & 0.08543 & 0.03513 \\
7 & 0.02099 & 0.00898 & 0.10311 & 0.04301
\end{tabular}


Evaluasi Premi Last Survivor Pasangan Suami Istri Menggunakan Metode Copula Frank

\begin{tabular}{ccccc}
8 & 0.02286 & 0.00978 & 0.12193 & 0.05160 \\
9 & 0.02492 & 0.01058 & 0.14200 & 0.06087 \\
10 & 0.02706 & 0.01147 & 0.16339 & 0.07081 \\
\hline \multicolumn{5}{c}{} \\
\hline$(5)$ & $(6)$ & $(7)$ & $(8)$ & $(9)$ \\
$\alpha=-3.3$ & $\alpha=-3$ & $\alpha=-2.5$ & $\alpha=-2$ & $\alpha=-1.5$ \\
\hline 0.00000 & 0.00000 & 0.00000 & 0.00000 & 0.00000 \\
0.00019 & 0.00017 & 0.00015 & 0.00013 & 0.00011 \\
0.00080 & 0.00073 & 0.00063 & 0.00054 & 0.00045 \\
0.00189 & 0.00172 & 0.00151 & 0.00129 & 0.00109 \\
0.00352 & 0.00323 & 0.00283 & 0.00245 & 0.00208 \\
0.00577 & 0.00530 & 0.00467 & 0.00406 & 0.00346 \\
0.00870 & 0.00803 & 0.00711 & 0.00620 & 0.00532 \\
0.01242 & 0.01149 & 0.01022 & 0.00896 & 0.00773 \\
0.01700 & 0.01578 & 0.01410 & 0.01242 & 0.01077 \\
0.02250 & 0.02096 & 0.01882 & 0.01666 & 0.01452 \\
0.02898 & 0.02708 & 0.02444 & 0.02175 & 0.01907 \\
\hline
\end{tabular}

\begin{tabular}{ccccc}
\hline$(10)$ & $(11)$ & $(12)$ & $(13)$ & $(14)$ \\
$\alpha=-1$ & $\alpha=1$ & $\alpha=-3.3$ & $\alpha=-3$ & $\alpha=-2.5$ \\
\hline 0.00000 & 0.00000 & 0.00019 & 0.00017 & 0.00015 \\
0.00009 & 0.00003 & 0.00061 & 0.00055 & 0.00048 \\
0.00038 & 0.00014 & 0.00109 & 0.00100 & 0.00088 \\
0.00091 & 0.00035 & 0.00164 & 0.00151 & 0.00133 \\
0.00173 & 0.00069 & 0.00225 & 0.00208 & 0.00185 \\
0.00290 & 0.00117 & 0.00295 & 0.00274 & 0.00245 \\
0.00448 & 0.00185 & 0.00375 & 0.00349 & 0.00314 \\
0.00655 & 0.00277 & 0.00463 & 0.00434 & 0.00392 \\
0.00917 & 0.00399 & 0.00560 & 0.00526 & 0.00478 \\
0.01244 & 0.00556 & 0.00663 & 0.00626 & 0.00573 \\
0.01644 & 0.00755 & 0.00775 & 0.00734 & 0.00676 \\
\hline & & & & \\
\hline$(15)$ & $(16)$ & $(17)$ & $(18)$ & $(19)$ \\
$\alpha=-2$ & $\alpha=-1.5$ & $\alpha=-1$ & $\alpha=1$ & $\mathrm{v}^{\mathrm{k}}$ \\
\hline 0.00013 & 0.00011 & 0.00009 & 0.00003 & 1.00000 \\
0.00041 & 0.00035 & 0.00029 & 0.00011 & 0.94340 \\
0.00076 & 0.00064 & 0.00053 & 0.00021 & 0.89000 \\
0.00115 & 0.00099 & 0.00083 & 0.00033 & 0.83962 \\
0.00161 & 0.00139 & 0.00117 & 0.00049 & 0.79209 \\
0.00215 & 0.00186 & 0.00158 & 0.00068 & 0.74726 \\
0.00278 & 0.00242 & 0.00207 & 0.00092 & 0.70496 \\
0.00349 & 0.00307 & 0.00265 & 0.00122 & 0.66506 \\
0.00429 & 0.00379 & 0.00330 & 0.00158 & 0.62741 \\
0.00517 & 0.00461 & 0.00404 & 0.00200 & 0.59190 \\
0.00615 & 0.00552 & 0.00488 & 0.00252 & 0.55839 \\
\hline & & & &
\end{tabular}

\begin{tabular}{ccccc}
\hline$(20)$ & $(21)$ & $(22)$ & $(23)$ & $(24)$ \\
$\alpha=-3.3$ & $\alpha=-3$ & $\alpha=-2.5$ & $\alpha=-2$ & $\alpha=-1.5$ \\
\hline 1.00000 & 1.00000 & 1.00000 & 1.00000 & 1.00000 \\
0.94322 & 0.94323 & 0.94326 & 0.94328 & 0.94330 \\
0.88929 & 0.88935 & 0.88944 & 0.88952 & 0.88959 \\
0.83804 & 0.83817 & 0.83836 & 0.83853 & 0.83870 \\
0.78930 & 0.78954 & 0.78985 & 0.79016 & 0.79045 \\
0.74295 & 0.74329 & 0.74377 & 0.74423 & 0.74467 \\
0.69882 & 0.69930 & 0.69995 & 0.70059 & 0.70121 \\
0.65680 & 0.65741 & 0.65826 & 0.65910 & 0.65992 \\
0.61675 & 0.61751 & 0.61856 & 0.61962 & 0.62066 \\
0.57858 & 0.57949 & 0.58076 & 0.58204 & 0.58330 \\
0.54221 & 0.54327 & 0.54475 & 0.54625 & 0.54775 \\
\hline
\end{tabular}

\begin{tabular}{ccccc}
\hline$(25)$ & $(26)$ & $(27)$ & $(28)$ & $(29)$ \\
$\alpha=-1$ & $\alpha=1$ & $\alpha=-3.3$ & $\alpha=-3$ & $\alpha=-2.5$ \\
\hline 1.00000 & 1.00000 & 0.00018 & 0.00016 & 0.00014 \\
0.94331 & 0.94337 & 0.00054 & 0.00049 & 0.00043 \\
0.88966 & 0.88987 & 0.00092 & 0.00084 & 0.00073 \\
0.83886 & 0.83932 & 0.00130 & 0.00119 & 0.00105 \\
0.79072 & 0.79155 & 0.00168 & 0.00155 & 0.00138 \\
0.74509 & 0.74638 & 0.00207 & 0.00192 & 0.00172 \\
0.70180 & 0.70365 & 0.00247 & 0.00230 & 0.00207 \\
0.66070 & 0.66321 & 0.00287 & 0.00269 & 0.00243 \\
0.62166 & 0.62491 & 0.00326 & 0.00306 & 0.00279 \\
0.58453 & 0.58861 & 0.00362 & 0.00342 & 0.00314 \\
\hline
\end{tabular}

\begin{tabular}{lllll}
\hline 0.54922 & 0.55418 & 0.00396 & 0.00376 & 0.00348 \\
\hline
\end{tabular}

\begin{tabular}{cccc}
\hline$(30)$ & $(31)$ & $(32)$ & $(33)$ \\
$\alpha=-2$ & $\alpha=-1.5$ & $\alpha=-1$ & $\alpha=1$ \\
\hline 0.00012 & 0.00010 & 0.00008 & 0.00003 \\
0.00037 & 0.00031 & 0.00026 & 0.00010 \\
0.00063 & 0.00054 & 0.00045 & 0.00018 \\
0.00091 & 0.00078 & 0.00065 & 0.00026 \\
0.00120 & 0.00103 & 0.00087 & 0.00036 \\
0.00151 & 0.00131 & 0.00111 & 0.00048 \\
0.00184 & 0.00160 & 0.00137 & 0.00061 \\
0.00217 & 0.00191 & 0.00165 & 0.00076 \\
0.00251 & 0.00222 & 0.00194 & 0.00093 \\
0.00284 & 0.00254 & 0.00223 & 0.00111 \\
0.00317 & 0.00285 & 0.00253 & 0.00132 \\
\hline
\end{tabular}

Nilai parameter dependensi $\alpha=-3,367$ menunjukkan angka mortalitas yang sangat tinggi sehingga premi yang dihasilkan paling mahal jika dibandingkan dengan parameter dependensi yang lain. Nilai parameter $\alpha=1$ menunjukkan angka mortalitas last survivor yang menurun sehingga premi yang dihasilkan paling murah di antara parameter dependensi yang lain. Nilai parameter dependensi $\alpha$ yang mendekati nol menunjukkan independensi mortalitas pasangan suami-istri.

2. Andaikan pasangan suami-istri yang berturut-turut berusia 54 tahun dan 43 tahun mengasuransikan diri mereka dengan mengambil polis last survivor berjangka 10 tahun dengan benefit sebesar Rp. 100000 000, dan suku bunga 6\%.

Karena usia pasangan suami-istri dibawah 55 tahun maka Premi Tunggal Bersih dihitung dengan mengasumsikan mortalitas pasangan suami istri yang independen dan tingkat lapse $5 \%$ sampai terjadi kematian pertama dan $1 \%$ setelahnya. Besar premi adalah

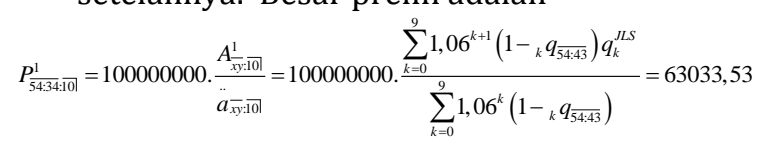

dengan perhitungan sebagai berikut :

\begin{tabular}{cccc}
\hline $\mathrm{x}=54$ & $(1)$ & $(2)$ & $(3)$ \\
$\mathrm{y}=43$ & $\begin{array}{c}\text { Probabilitas Terjadi Lapse } \\
\text { pada Akhir Tahun ke-k+1 }\end{array}$ & & \\
& ${ }^{A} r_{x y}$ & ${ }_{k+1}^{B} r_{x y}$ & ${ }_{k+1}^{C} r_{x y}$ \\
$\mathrm{k}$ & ${ }_{k+1}{ }_{x y}$ & $x_{h}$ & $y_{h}$ \\
0 & $x_{h}$ dan $y_{h}$ & $1.00 \%$ & $1.00 \%$ \\
1 & $5.00 \%$ & $1.00 \%$ & $1.00 \%$ \\
2 & $5.00 \%$ & $1.00 \%$ & $1.00 \%$ \\
3 & $5.00 \%$ & $1.00 \%$ & $1.00 \%$ \\
4 & $5.00 \%$ & $1.00 \%$ & $1.00 \%$ \\
5 & $5.00 \%$ & $1.00 \%$ & $1.00 \%$ \\
6 & $5.00 \%$ & $1.00 \%$ & $1.00 \%$ \\
7 & $5.00 \%$ & $1.00 \%$ & $1.00 \%$ \\
8 & $5.00 \%$ & $1.00 \%$ & $1.00 \%$ \\
\hline
\end{tabular}




\begin{tabular}{cccc}
\hline 9 & $5.00 \%$ & $1.00 \%$ & $1.00 \%$ \\
10 & $5.00 \%$ & $1.00 \%$ & $1.00 \%$ \\
\hline
\end{tabular}

\begin{tabular}{ccccc}
\hline (4) & $(5)$ & $(6)$ & $(7)$ & $\begin{array}{c}(8)=(4) \mathrm{x}(5) \\
\text { Keduanya } \\
\text { Meninggal }\end{array}$ \\
$q_{x+k}$ & $q_{y+k}$ & ${ }_{k} q_{x}$ & ${ }_{k} q_{y}$ & $q_{\overline{x+k: y+k}}$ \\
\hline 0.00749 & 0.00188 & 0.00000 & 0.00000 & 0.00001 \\
0.00795 & 0.00206 & 0.00749 & 0.00188 & 0.00002 \\
0.00846 & 0.00224 & 0.01537 & 0.00393 & 0.00002 \\
0.00906 & 0.00244 & 0.02370 & 0.00617 & 0.00002 \\
0.00981 & 0.00263 & 0.03255 & 0.00859 & 0.00003 \\
0.01071 & 0.00282 & 0.04204 & 0.01120 & 0.00003 \\
0.01176 & 0.00301 & 0.05230 & 0.01399 & 0.00004 \\
0.01293 & 0.00320 & 0.06345 & 0.01695 & 0.00004 \\
0.01416 & 0.00343 & 0.07556 & 0.02010 & 0.00005 \\
0.01536 & 0.00370 & 0.08865 & 0.02347 & 0.00006 \\
0.01656 & 0.00400 & 0.10265 & 0.02707 & 0.00007 \\
\hline
\end{tabular}

\section{KESIMPULAN}

1. Produk asuransi Last Survivor berjangka untuk pasangan suami-istri yang berusia 55 tahun keatas, premi dimodelkan dengan asumsi dependensi mortalitas pasangan suami istri menggunakan copula Frank, asumsi ini diciptakan sebagai perlindungan terhadap resiko finansial perusahaan asuransi,

2. Produk asuransi Last Survivor berjangka untuk pasangan suami-istri yang berusia di bawah 55 tahun ke bawah, premi dimodelkan menggunakan asumsi independensi mortalitas pasangan suami-istri dan asumsi lapse pada setiap status polis Last Survivor.

\section{REFERENSI}

[1] Bowers, Newton L, Jr.,Gerber, Hans U,.etc.1997. Actuarial Mathematics, Second Ed.The Society of Actuaries. Schaunburg Illinois

[2] Frasier, W. M. 1978. Second To Die Joint Life Cash Value And Reverses. The Actuary (April) : 4

[3] Frees, E. W., Carriere, and E. Valdez. 1995. Annuity Valuation With Dependent Mortality. Actuarial Research Clearing House $2: 31-80$

[4] Gusti Arlina. 2003. Kekerapan Tuberkolosis Paru pada Pasangan Suami-Istri Penderita Tuberkolosis Paru yang Berobat di Bagian Paru RSUP Adam Malik. Universitas Sumatera Utara
[5] Heekyung Youn, Shemyakin Arkady.1999. Statistical Aspect Of Joint Life Insurance Pricing. American Stat. Association : 34-38

[6] Kellison, Stephen G. 1991. The Theory of Interest. Edisi Kedua. Irwin McGraw-Hill : United State Of America

[7] Margus, Paul. 2002. Generalized Frasier Claim Rates under Survivorship Life Insurance Policies. NAAJ

[8] M. Atoillah I, Dr. 2007. Epidemiologi Hepatitis B

[9] National Vital Statistics Report, Vol 56, No. 9, 28 Desember 2007

[10] Nelsen, B. Roger. 2005. An Introduction to Copula. Springer-Verlag, New York

[11] P Feferman A. 2005. Broken Heart Syndrome. Universidade Federal de Sao Paulo : Brazil

[12] Sembiring, R.K.Ph.D.2001. Buku Materi Pokok Asuransi Jiwa I dan Asuransi Jiwa II. Karunika Jakarta : Universitas Terbuka 